\title{
PERAN KANOPI POHON SEBAGAI ECOSYSTEM SERVICES BERBASIS IKLIM MIKROTERHADAP KENYAMANAN PENGENDARA MOTOR DI SELAPARANG KOTA MATARAM
}

\author{
Munawir Sazali ${ }^{1 *}$, Laili Indana Zulpa ${ }^{2}$, Ilham Kusuma ${ }^{3}$, Edwin Pane ${ }^{4}$ \\ ${ }^{1,2,3}$ IPA Biologi Universitas Islam Negeri Mataram \\ ${ }^{4}$ Dinas Tata Ruang Kota Mataram \\ *Email: sazali.bione@uinmataram.ac.id
}

\begin{abstract}
Abstrak
Ecosystem services merupakan pelayanan yang diberikan alam untuk kebutuhan manusia, ecosystem sevicesini berupa naungan dari kanopi pohon yang ditujukan untuk kenyamanan beraktifitas bagi pengendara sepeda motor secara langsung yang diberikan oleh ekosistem. Tujuan penelitian untuk melihat peran kanopi pohon di beberapa persimpangan jalan Kecamatan Selaparang dalam berkontribusi memberikan rasa nyaman saat berada di lampu pemberhentian pada siang hari dengan indikasi berupa mematuhi rambu-rambu lalulintas di area traffic light. Penelitian ini memanfaatkan metode expost pasto dengan mengkaji hubungan lebih dari satu vaiabel bebas (luasan kanopi, iklim mikro dan respon pengendara) terhadap tingkat pelanggaran traffic light di persimpangan jalan Kecamatan Selaparang. Kanopi pohon sebagai sumber kajian dalam penelitian ini memberikan pengaruh besar terhadap tingkat kenyamanan pengendara pengguna sepeda motor di persimpangan jalan Kecamatan Selaparang, berdasarkan hasil analisis data berupa korelasi sumbangan relative dan efektive sebesar 73,6\% untuk luasan kanopi sedangkan suhu dan kelembaban hanya berpengaruh 12,8\% dan sisanya adalah faktor luar dari pengamatan sebesar 14,6\%. Berdasarkan data tersebut diperlukan lebih banyak naungan alami dari pohon (trees canopy) untuk meningkatkan kenyamanan pengendara bermotor saat berada di persimpangan jalan.
\end{abstract}

Kata Kunci : ecosystem services, kanopi pohon, kenyamanan berkendara.

\section{PENDAHULUAN}

Perubahan kondisi lingkungan yang sudah dirasakan membuat kenyamanan dalam beraktifitas banyak dikeluhkan masyarakat, terutama terkait suhu lingkungan yang terus mengalami peningkatan. Suhu atmosfer Bumi secara rata-rata meningkat menjadi $0,5^{\circ} \mathrm{C}$ lebih panas setiap tahunnya dibanding suhu pada zaman pra-industri (Murdiyarso. 2003). Intergovernmental Panel on Climate Change (IPCC) mempublikasikan hasil pengamatan ilmuwan dari berbagai Negara. Data-data tersebut menyimpulkan bahwa selama tahun 1880-2012, ternyata telah terjadi peningkatan suhu merata di seluruh bagian biosper sekitar $0,85(0,65$ $1,06)^{\circ} \mathrm{C}$. IPCC memprediksi peningkatan suhu rata-rata global akan meningkat $1,4-5,8^{\circ} \mathrm{C}(2,5-$ $10,4^{\circ} \mathrm{F}$ ) pada tahun 2100 (National Researcher Council. 2014\&IPCC, 2015).

Gejala peningkatan suhu udara sering dirasakan pada siang hari di daerah perkotaan dengan mobilitas penduduk yang tinggi. Data stasiun klimatologi I Kota Mataram pada tahun 2007 tercatat suhu udara tertinggi pada siang hari berkisar antara $23,40-31,40^{\circ} \mathrm{C}$, mengalami peningkatan pada tahun 2010 dengan suhu udara rata-rata mencapai 23,91 sampai dengan $31,94^{\circ} \mathrm{C}$ (Bapeda dan BPS Kota Mataram. 2012). Berdasarkan data BMKG Mataram rata-rata peningkatan suhu udara di kota Mataram selama 3 (tiga) tahun adalah 0,51 hingga $0,54^{\circ} \mathrm{C}$ dari peningkatan suhu secara rata-rata ini paling besar disebabkan oleh peningkatan volume kendaraan, sehingga menimbulkan efek meningkatnya ambian polusi udara di wilayah perkotaan (Hirota. 2010 \& Caiazzo, 2013). Sementara itu, pemanfaatan kendaraan bermotor semakin dirasakan oleh masyarakat untuk kebutuhan mobilitas barang dan jasa (Oliviani dan Guntur, 2014).

Transportasi di wilayah Kota Mataram semakin meningkat seiring dengan meningkatnya jumlah mobilitas penduduk terutama kendaraan bermotor. Hal ini didukung oleh peningkatan jumlah kendaraan bermotor setiap tahunnya yang berpengaruh langsung terhadap peningkatan emisi gas buang kendaraan bermotor di udara. Badan Pusat Statistik Republik Indosesia menyatakan bahwa kenaikkan kendaraan bermotor di Indonesia tahun 2005-2008 naik hingga 71\%. Oleh karena itu, perlu dilakukan penanganan secara efektif baik 
dari pemerintah dan masyarakat untuk mengurangi gas buang yang berdampak terhadap peningkatan suhu lingkungan.

Pohon merupakan jenis tumbuhan berkayu yang mampu tumbuh besar dengan memanfaatkan hasil-hasil emisi buangan berupa karbon sebagai sumber pembentukan energi dan menghasilkan $\mathrm{O}_{2}$ melalui fotosintesis (Hanafri, 2011).Chen,(2016)dan menjelaskan bahwa pohon dapat mereduksi polusiyang terdapat di udara, seperti gas CO di udara $(0,06-0,57)$ lebih besar dibandingkan dengan rumput $(0,14-0,35 \mathrm{mg})$. Selain itu, pohon juga bermanfaat sebagai naungan atau kanopi dari pancara panas cahaya matarahari sehingga kanopi pohon memberikan rasa nyaman bagi manusia atau hewan dalam melakukan aktifitas disiang hari (Alabi dan Christian. 2013). Dalam kajian ilmu lingkungan selalu terjadi interaksi antara mahluk hidup dengan lingkungan dan mahluk hidup dengan mahluk hidup lainnya, untuk mendapatkan interaksi yang positif dengan lingkungan maka perlu dilakukan rekonstruksi alur interaksi yang mengarah pelayanan ekosistem (ecosystem services)Bourguignon (2015).

Ecosystem sevices dalam penelitian ini lebih ditekankan pada pelayanan keteraturan dalam hal kondusifitas (kenyamanan) dan purifikasi karbon di udara. Pelayanan ekosistem ini berupa naungan dari pohon (threes canopy) yang ditujukan untuk manusia dalam kenyamanan beraktifitas di luar ruangan sehingga secara langsung merasakan pelayanan yang diberikan oleh ekosistem. Kajian penelitian ini akan melihat peran kanopi pohon di beberapa persimpangan jalan Kota Mataram dalam berkontribusi memberikan rasa nyaman, yakni berupa kenyamanan berkendara saat berada di lampu pemberhentian pada siang hari dengan indikasi berupa para pengendara bermotor mematuhi rambu-rambu lalulintas.

\section{METODE PENELITIAN}

\subsection{Lokasi Penelitian}

Penelitian ini difokuskan untuk melihat tingkat pelanggaran dari pengaruh yang ditimbulkan dari kondisi kanopi pohon di sekitar persimpangan jalan Kecamatan Selaparang. Selaparang merupakan wilayah yang terdapat di Kota Mataram yang berbatasan dengan Kecamatan Ampenan, Sekarbela, Mataram, Sandubaya dan Gunung Sari. Pengamatan dilakukan pada 7 (tujuh) titik pengamatan yang terdapat di persimpangan jalan Kecamatan Selaparang yang memiliki rambu-rambu lalulitas (traffic light) dengan tekhnik purposive sampling.

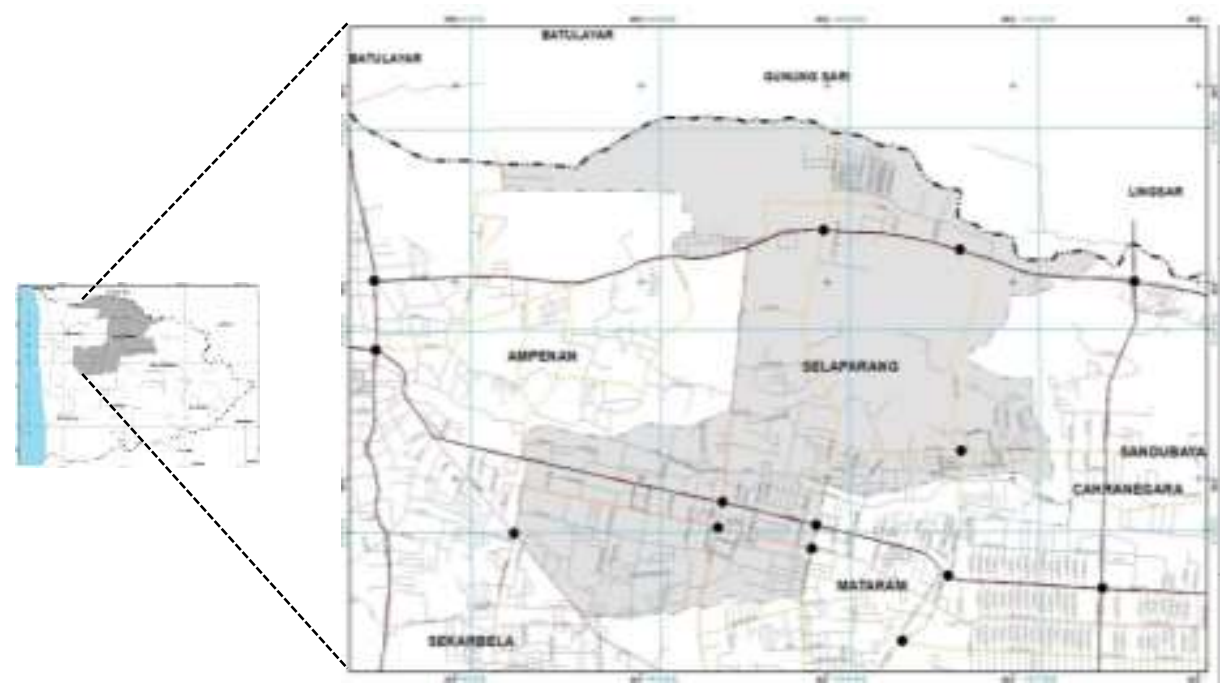

Gambar 1. Peta Titik Pengamatan di Kecamatan Selaparang 
Titik pengamatan pada gambar di atas ditunjukkan pada titik hitam yang berada pada persimpangan jalan Kecamatan Selaparang. Lokais pengamatan berada pada 7 (tujuh) titik dan diperluas sekitar 20 meter dari titik pengamatan untuk melihat kondisi lalu lintas dan luasan kanopi pada titik pengamatan yang ditentukan dengan ArcGIS 10. Pengematan dilakukan selama tiga kali pengamatan mulai dari pukul 10.00, 12.00 dan 14.00 WITA, proses pengamatan ini mengumpulkan data pengamatan berupa luasan kanopi, jumlah pelanggaran dan suhu mikro. Titik pengamatan ditentukan dengan digitasi peta Kota Mataram untuk mendapatkan titik koordnat lokasi pengamatan.

\subsection{Iklim Mikro}

Iklim mikro terdiri dari suhu, kelembababn dan intesitas cahaya serta didukung dengan data titik koordinat lokasi. Setiap pengukuran dilakukan dengan alat masing-masing berupa thermometer, hygrometer dan GPS serta dilenngkapi dengan peta digitasi Kota Mataram. Pengamatan dilakukandengan tiga ulangan pada pukul 10.00, 12.00 dan 14.00 WITA. Data masing-masing pengukuran kemudian dirata-ratakan.

\subsection{Luasan Kanopi dan Kenyamanan}

Luasan kanopi Kenyamanan akan diukur berdasarkan luasan bayangan yang ditimbulkan oleh pohon pada titik pengamatan dengan disesuaikan pada kondisi waktu pagi, siang dan sore hari. Luasan kanopi akan menjadikan tingkat kenyamanan saat berkendara bagi pengguna speda motor, kenyemanan ditentukan dengan terjadinya tingkat kepatuhan terhadap rambu-rambu lalu lintas (traffic light).

\subsection{Analisis Data Kenyamanan}

Menentukan tingkat korelasi antara masing-masing faktor yang berperan dalam tingkat kenyamanan pengendara sepeda motor, dilakukan uji korelasi dengan bantuan SPSS.17. Sumbangan efektif korelasi antara luasan kanopi dan suhu terhadap tingkat pelanggaran (refleksi kenyamana pengendara bermotor) di titik pengamatan persimpangan jalan Kota Mataram dengan formulasi sebagai berikut:

$$
S E=\frac{r_{y 1}-r_{y 2} r_{12}}{1-r_{12}^{2}} r_{y 1}
$$

\section{HASIL DAN PEMBAHASAN}

Kota Mataram merupakan salahsatu pusat aktifitas di Provinsi Nusa Tenggara Barat, letak wilayah Kota Mataram diapit oleh kabupaten Lombok Barat dan Selat Lombok pada $80^{\circ}$ $33^{\prime}-08^{\circ} 38^{\prime}$ lintang selatan dan $160^{\circ} 04^{\prime}-116^{\circ} 10^{\prime}$ bujur timur. Luas wilayah Kota Mataram adalah $61,30 \mathrm{~km}^{2}$ yang terbagi dalam 6 kecamatan, salah satunya adalah Kecamatan Sandubaya. Berdasarkan hasil surve awal ditentukan ada 7 (tujuh) titik pengamatan yang dipusatkan pada persimpangan jalan yang memiliki rambu-rambu lalulintas (traffic light).

Lokasi pengamatan yang dipusatkan pada titik-titik persimpangan jalan ditentukan dengan beberapa kriteria. Kriteria kanopi yang terbentuk ditentukan berdasarkan luasan yang menaungi permukaan jalan yang berada pada titik pengamatan, kriteria terbuka ditentukan dengan luasan kanopi di sepanjang jalan mencapai 0-14 $\mathrm{m}^{2}$, kriteria sedang ditentukan dengan luasan kanopi di sepanjang jalan mencapai $15-39 \mathrm{~m}^{2}$ dan kriteria untuk kondisi kanopi dengan luasan mencapai 40-80 $\mathrm{m}^{2}$ ditentukan sebagai kriteria berkanopi rindang. 
Tabel 1.Pengukuran Ecosystem Services untuk Kenyamanan Pengendara Sepeda Motor di Kecamatan Selaparang, Kota Mataram

\begin{tabular}{|c|c|c|c|c|}
\hline \multirow{2}{*}{$\begin{array}{c}\text { Persimpangan } \\
\text { Jalan }\end{array}$} & \multicolumn{3}{|c|}{ Ecosystem services } & \multirow{2}{*}{ Pelanggaran } \\
\hline & Kriteria Kanopi & Luas Kanopi & Suhu & \\
\hline Titik 1 & Rindang & 48.5 & 31.93 & 64 \\
\hline Titik 2 & Rindang & 37.5 & 31.87 & 51 \\
\hline Titik 3 & Sedang & 15.3 & 33.8 & 153 \\
\hline Titik 4 & Sedang & 13.5 & 38.23 & 190 \\
\hline Titik 5 & Sedang & 11.5 & 34.93 & 189 \\
\hline Titik 6 & Terbuka & 7.5 & 36.17 & 381 \\
\hline Titik 7 & Terbuka & 5 & 36.4 & 340 \\
\hline \multirow{3}{*}{ Korelasi } & Luas Kanopi & 1 & $-0.818^{*}$ & $-0.838 *$ \\
\hline & Suhu & $-0.818^{*}$ & 1 & $0.727^{*}$ \\
\hline & Pelanggaran & $-0.838^{*}$ & $0.727 *$ & 1 \\
\hline
\end{tabular}

Hasil analisis uji korelasi menunjukkan nilai masing-masing signifikasi antara luasan jumlah pelanggran dengan luasan kanopi dan suhu. Luasan kanopi dengan pelanggaran terlihat memiliki nilai person correlation $-0,838$ dan hubungan antara jumlah pelanggaran dan suhu memiliki nilai person correlation $-0,727$. Hal ini menunjukkan terdapat korelasi secara nyata untuk masing-masing pengamatan (person correlation) antara pelanggaran dengan luasan kanopi dan suhu. Hubungan antara luasan kanopi dan suhu dapat ditentukan bahwa antara kedua variabel ini terdapat hubungan (person correlation) sebesar $-0,818$. Untuk melihat hubungan antara setiap variabel, maka dilakukan uji regresi ganda antara setiap variabel telihat antar perlakuan (between group) sebesar 0,002 lebih kecil dibandingkan nilai signifikansi yang ditetapkan yaitu $\alpha=0,05(P<0,05)$. Berdasarkan hal ini, terdapat korelasi ganda antara jumlah pelanggaran di persimpangan jalan KecamatanSelaparang dengan luasan kanopi meskipun dalam bentuk korelasi negatifdan suhu dalam bentuk korelasi positif.

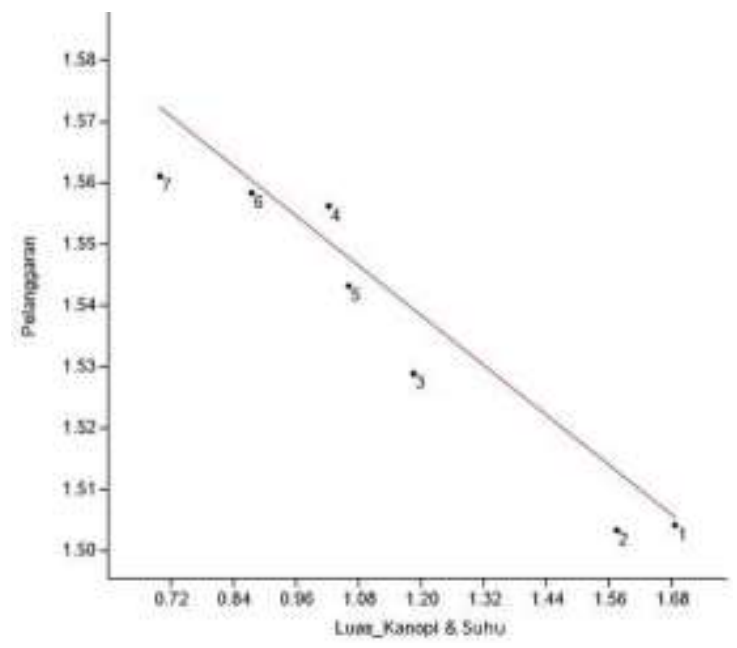

Gambar 2. Korelasi Ganda antara Jumlah Pelanggaran dengan Luasan Kanopi dan Suhu

Grafik di atas menunjukkan koefisien korelasi ganda, hal ini menunjukkan bahwa tingkat korelasi antara jumlah pelanggaran dan luasan kanopi serta suhu lingkungan terkait secara signifikan. Bentuk arah dari garis korelasi ini menunjukkan bahwa bentuk korelasi negatif, hal ini berarti setiapbentuk hubungan atau korelasi yang terbentuk saling bertolak. Mengartikan korelasi negative ini bahwa setiap peningkatan luasan kanopi maka akan semakin menurun tingkat pelanggaran di sekitar persimpangan jalan Kecamatan Selaparang, hal ini 
sangat terkait dengan faktor pendukung dari kenyamanan yang diberikan berupa peneduh dari pepohonan (Tauhid, 2008 \& Sitawati dan Suryanto, 2012)

Untuk melihat komposisi korelasi yang terbentuk dapat ditunjukkan pada grafik di atas. Antara suhu dan luasan kanopi memiliki hubungan di sebagian besar titik pengamatan, hal ini menunjukkan pengaruh suhu dan luasan kanopi terhadap tingkat pelanggaran memiliki korelasi dan berupa korelasi negatif (Loughner, 2012). Sumbangan pengaruh antara luasan kanopi dan suhu dapat di lihat pada hasil analisis korelasi sumbangan efektif dan sumbangan relative $x \_1$ dan $x \_2$ terhadap terjadinya regersi linier, terlihat bahwa luas kanopi memberikan sumbangan sebesar $73,6 \%$ dan suhu memberikan sumbangan sebesar $12,8 \%$ terhadap terjadianya tingkat pelanggaran. Terdapat pengaruh lain sebesar $14,6 \%$ yang berasal dari luar luasan kanopi dan suhu, faktor lain ini diasumsikan berasal dari tingkat internal pengendara sepeda motor dan faktor eksternal.

\section{KESIMPULAN}

Berdasarkan hasil analisis data dan pembahasan dari penelitian ini dapat disimpulkan bahwa, terdapat korelasi antara jumlah pelanggaran dengan luasan kanopi pohon dan suhu. Masing-masing variabel memberikan pengaruh besar terhadap tingkat kenyamanan pengendara pengguna sepeda motor di persimpangan jalan Kecmatan Selaparan dengan melihat korelasi sumbangan relative dan efektive sebesar $51,6 \%$ sedangkan suhu dan kelembaban hanya berpengaruh $11,8 \%$ dan sisanya adalah faktor luar dari pengamatan.

\section{DAFTAR PUSTAKA}

Bapeda dan BPS Kota Mataram. 2012. Mataram dalam Angka Tahun 2012. Mataram. BPS Kota Mataram. Hal. 4.

Caiazzo. F, Ashok A, Waitz I.A, Yim S.H.L, Barrett S.R.H. 2013. Air Pollution and Early Death in the United States. Part: I Quantifying the Impact Major Sector in 2005. Elsevier Atmospheric Environment Journal. Vol. 79. Hal. 198-208.

Chen Y, Li Y, Li J. 2016. Investigating the Influence of Tree Coverage on Street Crime: A Case Study in The City of Vancouver, British Columbia, Canada. The International Archives of the Photogrammetry, Remote Sensing and Spatial Information Sciences, Volume XLI-B2. Hal. 659-702.

Oliviani C dan GunturH.L. 2014. Analisa Kenyamanan Kendaraan Roda Dua dengan Pemodelan Pengendara sebagai Multi-Sistem. Jurnal Teknik Pomits. Vol. 3, Hal. 57-60.

Didier Bourguignon. 2015. Ecosystem Services Valuing Our Natural Capital. European Parliamentary Research Service. Hal. 2.

Holtan T.M,Dieterlen S.L, Sullivan W.C. 2014. Social Life Under Cover: Tree Canopy and Social Capital in Baltimore, Maryland. Journal Environment and Behavior. Vol. 6. Hal: 1-24.

Imawan Wahyu Hidayat. 2010. Kajian Fungsi Jalur Hijau Jalan Sebagai Penyangga Lingkungan pada Tol Jagorawi. Jurnal Manusia dan Lingkungan. Vol. 12. Hal.124-133.

Intergovernmental Panel on Climate Change (IPCC). 2015. Climate Change 2014 Synthesis Report. Geneva, Switzerland. IPCC publisher. Hal. 2-3

HanafriK.S. 2011. Analisis Manfaat Kanopi Pohon dalam Mereduksi Polutan Udara Menggunakan Program City-green di Jalan Raya Padjajaran, Kota Bogor. Institut Pertanian Bogor Press..

HirotaK. 2010. Comparative studies on Vehicle Related Policies for Air Pollution Reduction in Ten Asian Countries. Sustainability. Vol. 2, Hal. 145-164.

Loughner C.P, AllenJ.D, ZhangD.L, PickeringK.E, DickersonR.R, LandryL. 2012. Roles of Urban Tree Canopy and Buildings in Urban Heat Island Effects: Parameterization and Preliminary Results. Journal Applaid Meteorology and Climatology. Vol.15, Hal. 17751793

Alabi M.O dan Christian E.I. 2013. Street Tree Canopy Cover Variation Effects on Temperature in Lokoja, Nigeria. Journal of Agriculture and Environmental Sciences, Vol. 2 No. 2. Hal. 2531.

Murdiyarso. 2003. Sepuluh Tahun Perjalanan Negosiasi Konvensi Perubahan Iklim. Jakarta. Penerbit Buku Kompas. Hal. 82. 
National Researcher Council. 2014. A Report on Existing and Possible Tree Canopy in the City of Charlotte and Mecklenburg County, NC. Washington, DC: The National Academies Press.

Sitawati dan SuryantoA. 2012. Model Keterpaduan Pohon dalam Menentukan Indeks Kenyamanan Ruang Terbuka Hijau (RTH). Laporan Akhir Hasil Penelitian Unggulan Perguruan TinggiHibah Bersaing (Tahun Ke-1) Tahun Anggaran 2012. DIPA Universitas Brawijaya.

Tauhid. 2008. Kajian Jarak Jangkau Efek Vegetasi Pohon Terhadap Suhu Udara pada Siang Hari di Perkotaan (Studi Kasus: Kawasan Simpang Lima Kota Semarang). Semarang. Tesis Universitas Diponegoro. Hal. 4-5. 